\title{
Pleiotropic Effect of Aldosterone on Human Endothelial Cells In Vitro
}

\author{
Pezhman Mirshahi, Alexandre Berthaut, Elodie Ducros, Jeannette Soria, Manjul K. Agarwal and \\ Massoud Mirshahi*
}

UMRS 872, Centre de Recherches des Cordeliers, Faculté de Médecine Paris VI, 15 rue de l'Ecole de Médecine, 75006 Paris, France

\begin{abstract}
Aim: To investigate the effect of aldosterone and its antagonists on cell behavior and gene modulation in human endothelial cells.

Methods and Results: Exposure of HBMEC to $100 \mathrm{nM}$ aldosterone reduced the subsequent organization and assembly of cells into capillary-like networks, capillary length and cell multiplication but cell migration to the wound edge was not affected by the agonist. Eplerenone $(400 \mathrm{nM})$ partially reversed the inhibitory effect of the agonist on capillary length, the number of capillary networks, as well as cell multiplication; the antagonist also inhibited the migration of HBMEC in a wound healing assay. Aldactone was more potent than eplerenone in most of the tests, due possibly to the fact that the former derivative is not specific to the MCR but activates other classes of steroid receptors as well. Transcriptional modulation by aldosterone was analyzed using a gene array technique that screened 1800 genes related to cytokines, monokines, growth factors, angiogenic effectors, cell metabolism, growth and malignant transformation. Evidence is provided here for the simultaneous upregulation of 36 mRNAs, and concurrent downregulation of 29 mRNAs, in endothelial cells exposed for $8 \mathrm{~h}$ to $100 \mathrm{nM}$ aldosterone.

Conclusions: Aldosterone inhibits cell migration, network formation, and cell proliferation in vitro, possibly via a pleiotropic effect on transcription modulation in human endothelial cells.
\end{abstract}

Keywords: Aldactone, aldosterone, angiogenesis, endothelium, eplerenone, receptors.

\section{INTRODUCTION}

In the past, the body vasculature had generally been written off as a system of tubules connected end to end merely to facilitate blood flow. Of late, it has been recognized that $900 \mathrm{~m}^{2}$ or so of blood vessels form an important organ which assures body integrity in a number of ways [1-3]. Increasing evidence suggests that dysregulation of vessel growth underlies a myriad of disorders [3-5]. Inhibition of angiogenesis or capillary formation by angiostatin and endostatin is highly effective in tumor regression. Rheumatoid arthritis, diabetic retinopathy and psoriasis can also benefit from a similar therapy $[6,7]$. On the other hand, angiogenic stimulation may be useful in ischemic diseases and decubitus $[8,9]$. It therefore becomes important to delineate those factors that assure the genesis, maintenance, and renewal of body vasculature in health and disease.

The main, biologically active, component in the blood vessels consists of a single layer of endothelial cells that are insulated by an outer envelope consisting of pericytes, smooth muscle fibers, fibroblasts, the basement membrane, and an extracellular matrix [1]. Vascular endothelium is intimately linked to capillary formation, repair and remodeling of microcirculation [2]. It is well established that adrenocortical hormones exert pleiotropic effects on a wide

*Address correspondence to this author at the UMRS 872, Centre de Recherches des Cordeliers, Faculté de Médecine Paris VI, 15 rue de l'Ecole de Médecine, 75006 Paris, France;

Tel: 00331423469 31; Fax: 00331442781 61;

E-mails: dizbad2004@yahoo.fr, massoud.mirshahi@upmc.fr variety of cell types $[10,11]$ and influence various parameters in the cardiovascular tree [12-14]. We had previously shown $[16,17]$ that the mineralocorticoid receptor (MCR)mediated action of steroid hormones induces neosynthesis of the epithelial sodium channel [15] and also increases the cell volume of capillaries formed by human bone marrow endothelial cells (HBMEC). More recently, we had demonstrated that aldosterone modifies hemostasis via an upregulation of the protein-C receptor in HBMEC [18]. The results presented here demonstrate pleiotropic gene activation by the MCR-mediated action of aldosterone.

\section{MATERIALS AND METHODS}

HBMEC cultures, kindly provided by Pr. Pienta, were grown in M131 medium (Cascade Biologics, Portland, OR) supplemented with $10 \%$ Fetal Calf Serum (FCS) $100 \mathrm{IU} / \mathrm{ml}$ penicillin, $100 \mu \mathrm{g} / \mathrm{ml}$ streptomycin and $5 \%$ Microvascular growth supplement consisting of human basic fibroblast growth factor, heparin, human epidermal growth factor, and dibutyryl cyclic AMP (MVGS) obtained from Cascade Biologics, Inc.

\section{In Vitro Angiogenesis Assay}

The technique of Kern et al., (1983) [19] was adapted as follows: $1.5 \times 10^{5}$ HBMEC were cultured in 24 multiwell plates filled with M131 containing 5\% FCS, $100 \mathrm{IU} / \mathrm{ml}$ penicillin, $100 \mu \mathrm{g} / \mathrm{ml}$ streptomycin and 5\% MVGS. After 18 hours at $37^{\circ} \mathrm{C}$, the cells were carefully washed 2 times with RPMI and detached with a non-enzymatic solution containing accutase (PAA, France). The effect of aldosterone, aldactone and eplerenone on capillary formation 
was analyzed on low matrigel base in a medium devoid of growth factor. To this end, 96-well plates were pre-coated with matrigel (Becton-Dickinson, Le Pont de Claix, France) that was allowed to polymerize for $1-2$ hours at $37^{\circ} \mathrm{C}$. Thereafter, $100 \mu 1$ HBMEC ( $3.5 \times 10^{4}$ cells/ well) in M131, without FCS and MVGS, were seeded onto the matrigelcoated wells in presence of various concentrations and combinations of steroids. Following different incubation periods at $37^{\circ} \mathrm{C}$, capillary tube formation was assessed using an inverted microscope fitted with a digital camera (NikonDiafot). The capillary network was quantitated by recording the number and length of connections between three or more capillary-like structures/field with the aid of the Archimed program, developed by Microvision [20].

\section{Cell Migration}

$6 \times 10^{4}$ HBMEC were cultured in 24 well plates coated with $03 \%$ of gelatin in the presence of M131 containing 5\% FCS and $5 \%$ MVGS. After $18 \mathrm{~h}$, the semi-confluent cells were dislodged by a cell scraper on a standardized surface. The effect of aldosterone (100 nM), eplerenone (400 nM), aldactone $(400 \mathrm{nM})$, alone or in various combinations, on cell migration was quantitated by measuring the number of cells migrating to the wound edge after $6,18,27$ and $48 \mathrm{~h}$ incubation in a medium containing only $2 \%$ FCS to avoid cell proliferation.

\section{Cell Proliferation}

$6 \times 10^{4}$ HBMEC were cultured in 24 well plates in the presence of M 131 containing 10\% FCS and aldosterone, eplerenone or aldactone in desired combinations. After 0,18 and $36 \mathrm{~h}$, the cells were detached by trypsin and counted in the presence of Trypan blue.

\section{Gene Array Analysis}

The HBMEC cultures were exposed for $8 \mathrm{~h}$ to $100 \mathrm{nM}$ aldosterone in M131, twenty five million cells were lysed in Trizol reagent and shipped to Memorec on dry ice. RNA was extracted and hybridized on PIQOR ${ }^{\mathrm{tm}}$ microarrays, followed by linear amplification of RNA on oligo(dT)-T7 primed cDNA. Amplified RNA (aRNA) samples were quantitated by spectrophotometry and the sample quality was checked by gel electrophoresis (Bioanalyzer 2001, Agilent) as reported before [21]. The 1800 products in this microassay consisted of genes related to cytokines, monokines, growth factors, angiogenic effectors, cell metabolism, growth and
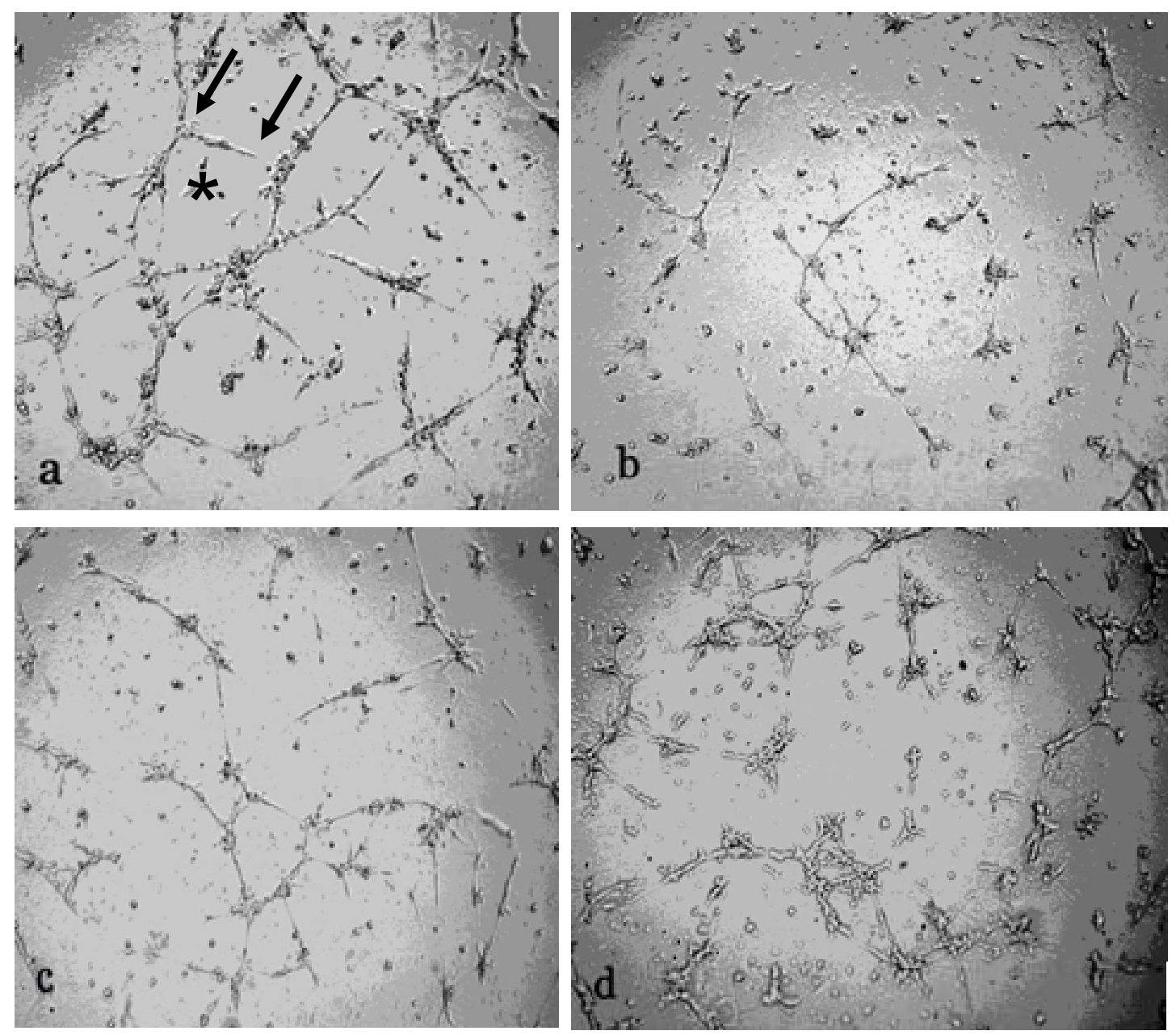

Fig. (1). Inhibition of HBMEC capillary length and abundance by aldosterone and eplerenone. HBMEC (30,000 cells) were exposed to 100 $\mathrm{nM}$ aldosterone (b), $400 \mathrm{nM}$ eplerenone (c), or the agonist plus the antagonist (d), for $18 \mathrm{~h}$ and thereafter layered on Matrigel for $18 \mathrm{~h}$. Archimed program of Microvision was used to quantitate the capillary length (arrows in a) and the number of networks $(*$ ) compared to control (a) in Fig. (1). 
malignant transformation. The experiment was repeated twice with four spots each time and is based on qPCR analysis.

\section{Statistics}

The student's t test was used to assess the significance between various groups; the $p$ values are shown in figure legends.

\section{RESULTS}

\section{Inhibition of HBMEC Network by Aldosterone}

Data in Fig. (1) show decreased number of HBMEC networks and capillary lengths as a result of exposure to either $100 \mathrm{nM}$ aldosterone (b), $400 \mathrm{nM}$ eplerenone (c) or a combination of the agonist plus the antagonist (d), $18 \mathrm{~h}$ after the cells were seeded on low Matrigel support; in contrast, aldosterone had no effect on high matrigel support [16].

(A)

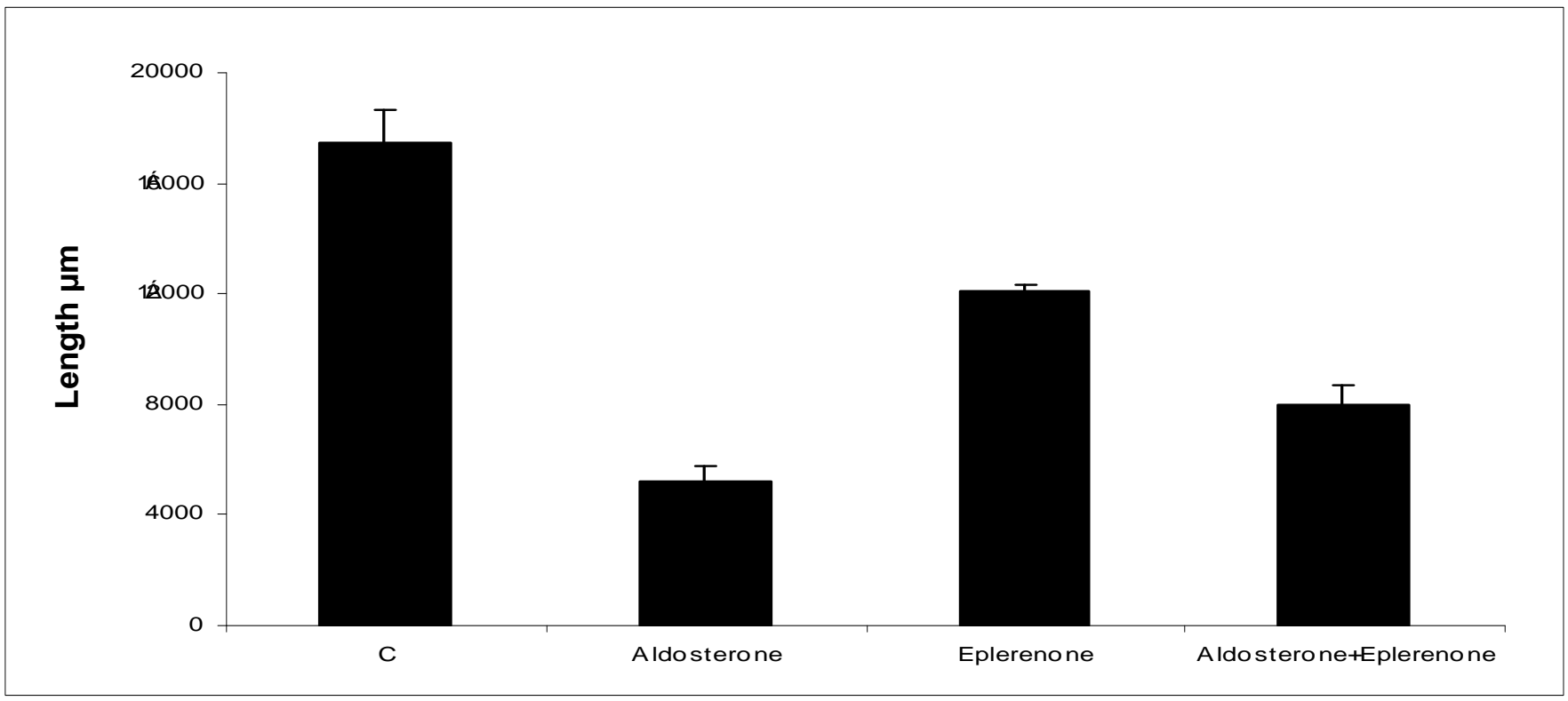

(B)

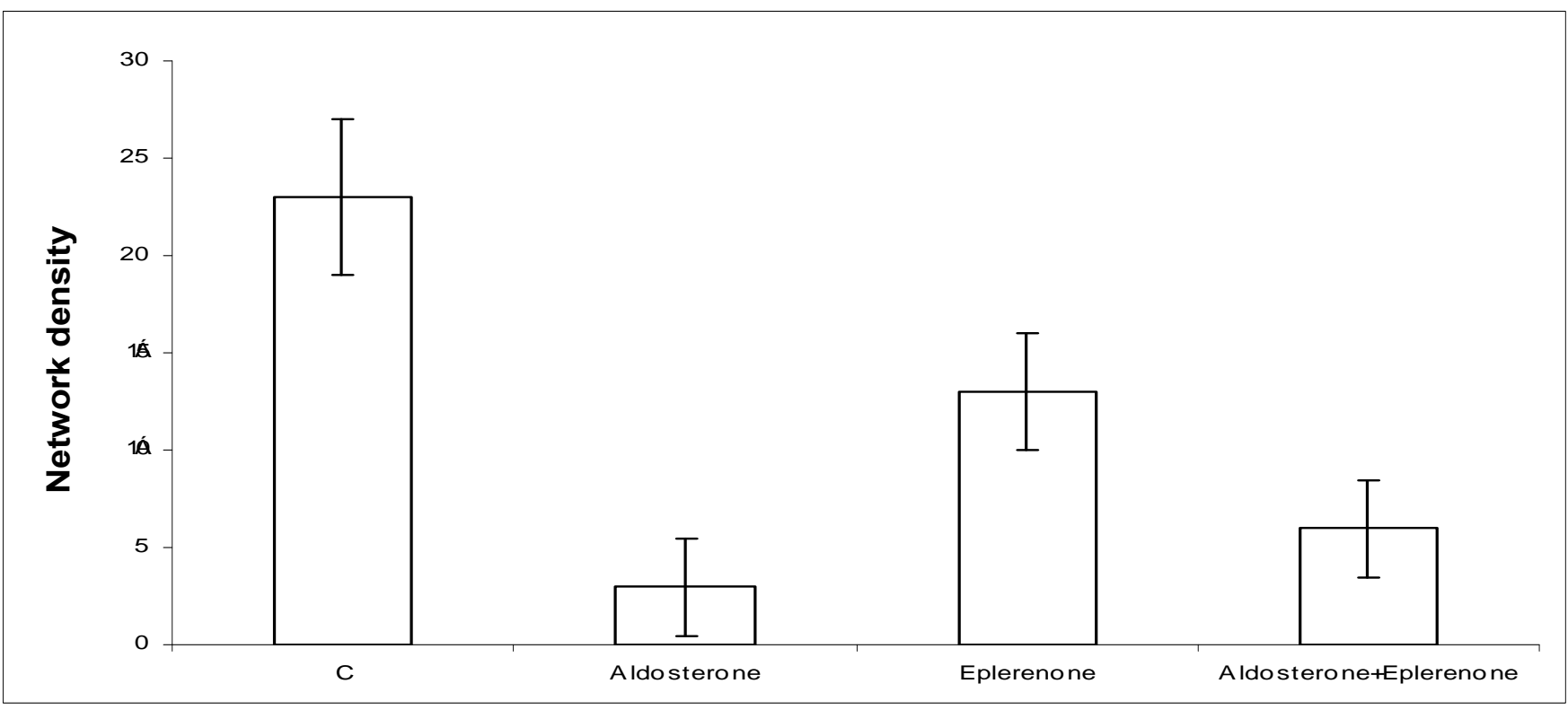

Fig. (2). Quantification of the number and the length of capillaries. The results, repeated three times, are expressed as the capillary length (Fig. 2A) and capillary number (Fig. 2B) as described in the Methods section. In Fig. (2A), compared to control all other columns show $\mathrm{p}<0.001$; compared to eplerenone alone both aldosterone and aldosterone + eplerenone also show $\mathrm{p}<0.001$. In Fig. (2B), compared to control, aldosterone alone, eplerenone alone or aldosterone + eplerenone $=\mathrm{p}<0.003$; eplerenone $v s$ aldosterone $=\mathrm{p}<0.003$; eplerenone $v s$ aldosterone + eplerenone $=\mathrm{p}<0.021$. 
Quantification by the Archimed program of Microvision revealed that the length of the capillaries decreased significantly from $17.000 \mathrm{~mm}$ in the control group (c) to $5.600 \mathrm{~mm}$ in the presence of $100 \mathrm{nM}$ aldosterone, and to $11000 \mathrm{~mm}$ in the presence of eplerenone alone (Fig. 2A). The potent inhibitory effect of aldosterone was partially attenuated by eplerenone such that the capillary length increased from, $5600 \mathrm{~mm}$ in the presence of aldosterone alone, to $8200 \mathrm{~mm}$ when the antagonist competed with the agonist. This suggests that both the agonist and the antagonist compete for MCR occupancy albeit the underlying mechanisms remain to be elucidated. Similarly, the number of capillary networks diminished significantly from 23 in the control group (c) to 3 and 12.5, in the presence of aldosterone and eplerenone, respectively (Fig. 2B). Again, eplerenone partially reversed the effect of aldosterone to raise the number of networks from 3 in the presence of the agonist alone to 6 when the antagonist was combined with the agonist (Fig. 2B). Similar results were obtained with aldactone when used in place of eplerenone (not shown).

\section{The Effect of Aldosterone and Eplerenone on HBMEC Migration}

Data in Fig. (3) show time dependent HBMEC migration to the wound edge on the gelatine support. The number of migrating cells diminished from 3120 in the control group (c) to 2810,2175 and 2420 in the presence of aldosterone, eplerenone, and aldosterone plus eplerenone, respectively, 48 $\mathrm{h}$ after a wound had been excised on the cell layer. In this test, aldosterone neither inhibited cell migration nor modified the significant inhibition observed with eplerenone. It would therefore appear that eplerenone possesses innate capacity to inhibit cell migration which is not dependent upon the antagonism of aldosterone action. Further experiments are needed to elucidate the action of eplerenone which assumes importance in view of the clinical use of the steroid [22, 23]. Interestingly, aldactone was even more potent than eplerenone in this context (data not shown) which may stem from the fact that it activates receptors for several steroid hormones ( 24 in contrast to the specificity of eplerenone for the MCR [22, 23].

\section{Inhibition of HBMEC Proliferation by Aldosterone and Eplerenone}

Data in Fig. (4) show that HBMEC proliferation, over the $36 \mathrm{~h}$ period, decreased from 550,000 in the control group to $380,000,455,000$ and 420,000 living cells in the presence of aldosterone, eplerenone and aldosterone plus eplerenone, respectively. Eplerenone was significantly less effective than aldosterone in inhibiting HBMEC proliferation and the agonist completely reversed the statistically insignificant inhibition observed with the antagonist alone. Aldactone was again more potent than eplerenone (not shown) possibly due to its affinity for various classes of steroid receptors [24].

Collectively, whereas eplerenone partially reversed both the angiogenic (Fig. 1) and growth (Fig. 4) inhibition by aldosterone the agonist did not influence cell migration at all (Fig. 3) which was effectively inhibited by eplerenone (Fig. 3). The reason(s) for these differences are not understood but could stem from the nature of gene(s) modified by MCR-

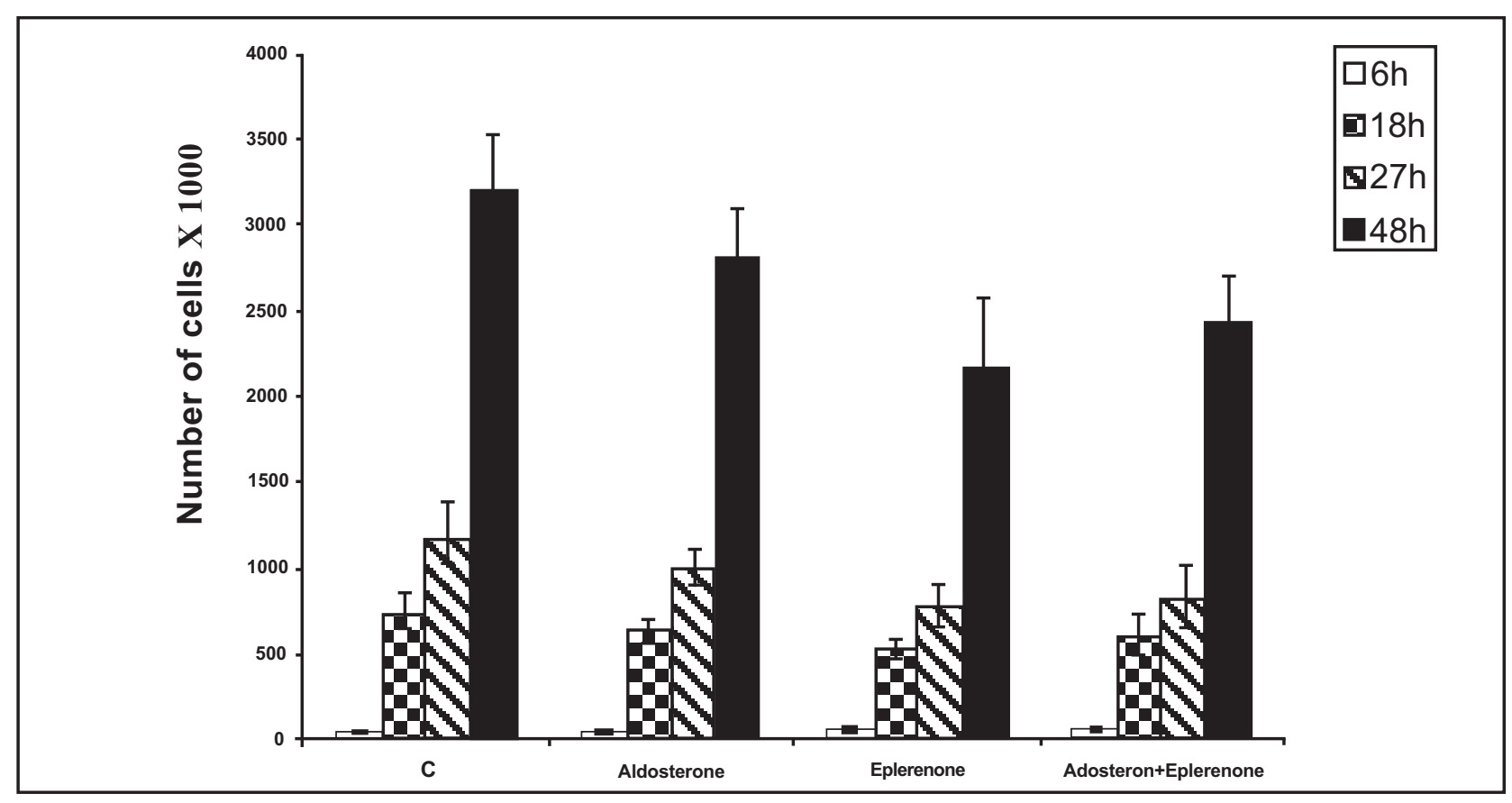

Fig. (3). The effect of aldosterone and eplerenone on HBMEC migration. HBMEC $(200,000)$, cultivated in M131 + $10 \%$ fetal calf serum, were layered on $0.3 \%$ gelatin for $18 \mathrm{~h}$ to attain $90 \%$ confluence. A fissure was incised by the technique of the Wound-healing test (Mirshahi et al., 2006). The flasks were cultivated in the presence of M $131+2 \%$ fetal calf serum and the number of cells migrating to the wound edge was quantitated by Archimed program of Microvision $6 \mathrm{~h}, 18 \mathrm{~h}, 27 \mathrm{~h}$ and $48 \mathrm{~h}$ later. The experiment was repeated eight times using control cultures, $100 \mathrm{nM}$ aldosterone, $400 \mathrm{nM}$ eplerenone, agonist plus antagonist, as described in the Methods section. After $48 \mathrm{~h}$ at $37^{\circ} \mathrm{C}$, compared to the control, eplerenone $=\mathrm{p}<0.003$; aldosterone + eplerenone $=\mathrm{p}<0.003$; aldosterone $=$ not significant (NS); aldosterone $v s$ eplerenone $=$ NS; eplerenone $v s$ aldosterone + eplerenone $=$ NS. 


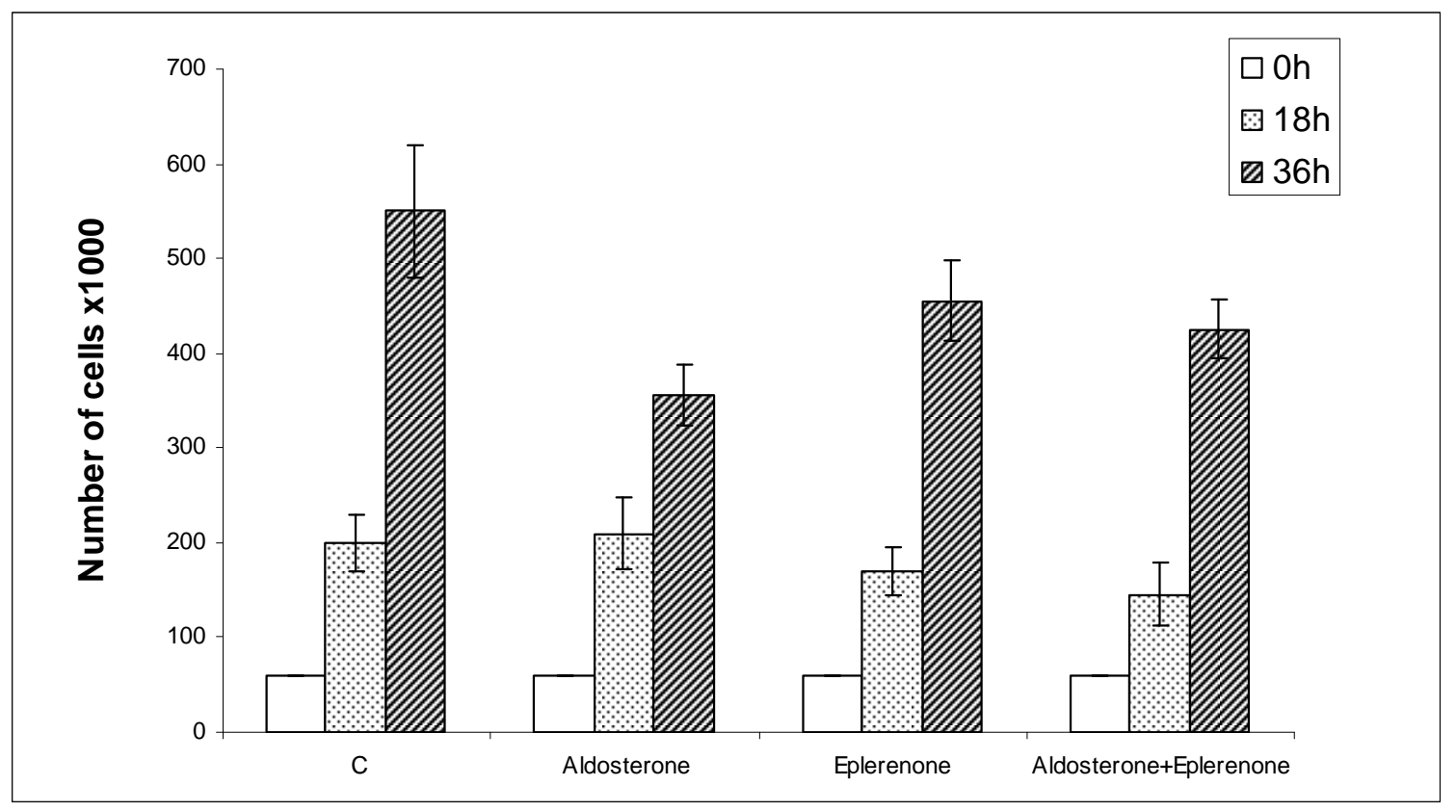

Fig. (4). Inhibition of HBMEC proliferation by aldosterone and eplerenone. HBMEC $(60,000)$ were cultivated in M131 $+10 \%$ fetal calf serum, detached by acutase, exposed to trypan blue and the surviving cells were counted 0,18 and $36 \mathrm{~h}$ later. The experiment was repeated five times with control cultures, $100 \mathrm{nM}$ aldosterone, $400 \mathrm{nM}$ eplerenone, agonist plus antagonist, as detailed in the Methods section. After 36 $\mathrm{h}$, compared to the control, aldosterone $=\mathrm{p}<0.001$; eplerenone $=\mathrm{p}>0.05$; aldosterone + eplerenone $=\mathrm{p}<0.001$; aldosterone $v s$ eplerenone $=$ $\mathrm{p}<0.003$.

mediated effect of aldosterone. In order to elucidate these relationships, a gene array analysis was performed to screen for those genes that could potentially respond to aldosterone. The 1800 products screened in this microassay represent genes that direct the synthesis of various cytokines, monokines, growth factors, angiogenic effectors, cell metabolism, cell growth and neoplasia.

\section{Gene Modulation by Aldosterone}

Data in Fig. (5) shows that the 28S/18S ratios were 1.72 and 1.85 , respectively, for the control and aldosterone treated groups. As the samples did not show any additional degradation peaks in the low molecular range they were suitable for gene array screening. Data in Table $\mathbf{1}$ show upregulation of 20 mRNAs, along with the concurrent downregulation of 10 mRNAs in HBMEC exposed for $8 \mathrm{~h}$ to $100 \mathrm{nM}$ aldosterone. In particular, the increase in mRNA for VEGF, CXCR-4, CDKN1A, Egr-1, EPCR, BCL-2, CD-24 and P-21 along with the decrease in the mRNA for NOD2, L1CAM, CD-83, ITGB-7, Cyclin-D, Cyclin-A, Decorin, GADD-135 and MMP-12, is in keeping with the accepted up and down regulation of these various factors in capillary formation. The table also provides the various synonyms in contemporary use to denote these various gene products. Altogether, 36 genes were up-regulated and 29 genes were down-regulated (details not shown).
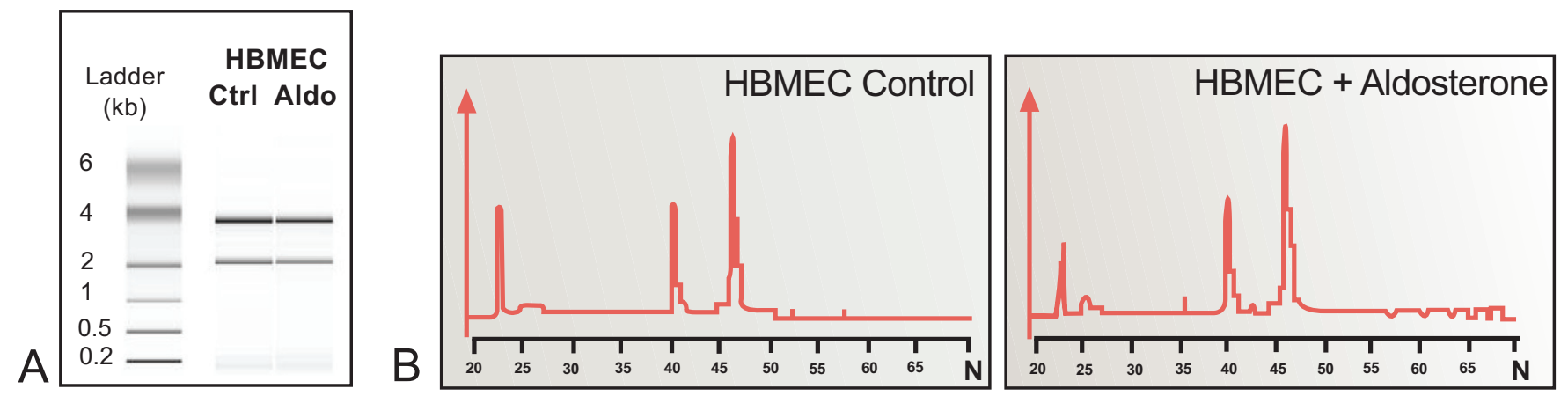

Fig. (5). Qualitative analysis of RNA used to assess gene modulation by aldosterone. Total RNA from HBMEC was electrophoresed on agarose (A) to verify the quality of mRNA. Electrophreograms (B) performed on the electrophoresis peaks permitted the calculation of $28 \mathrm{~S} / 18 \mathrm{~S}$ ratio. A value greater than 1.5 indicated qualitative integrity of the RNAs. Here, the ratios were 1.72 for the control and 1.85 for the aldosterone treated group. Furthermore, the samples did not show any additional degradation peaks in the low molecular weight range. These samples were used for linear amplification of 1800 genes that code for cytokines, monokines, growth factors, angiogenic effectors and cell metabolism, normal and malignant growth, as detailed in the Methods section. 
Table 1. Transactivation of Genes in HBMEC Exposed to $100 \mathrm{nM}$ Aldosterone for $6 \mathrm{~h}$, Assessed by Quantitative PCR

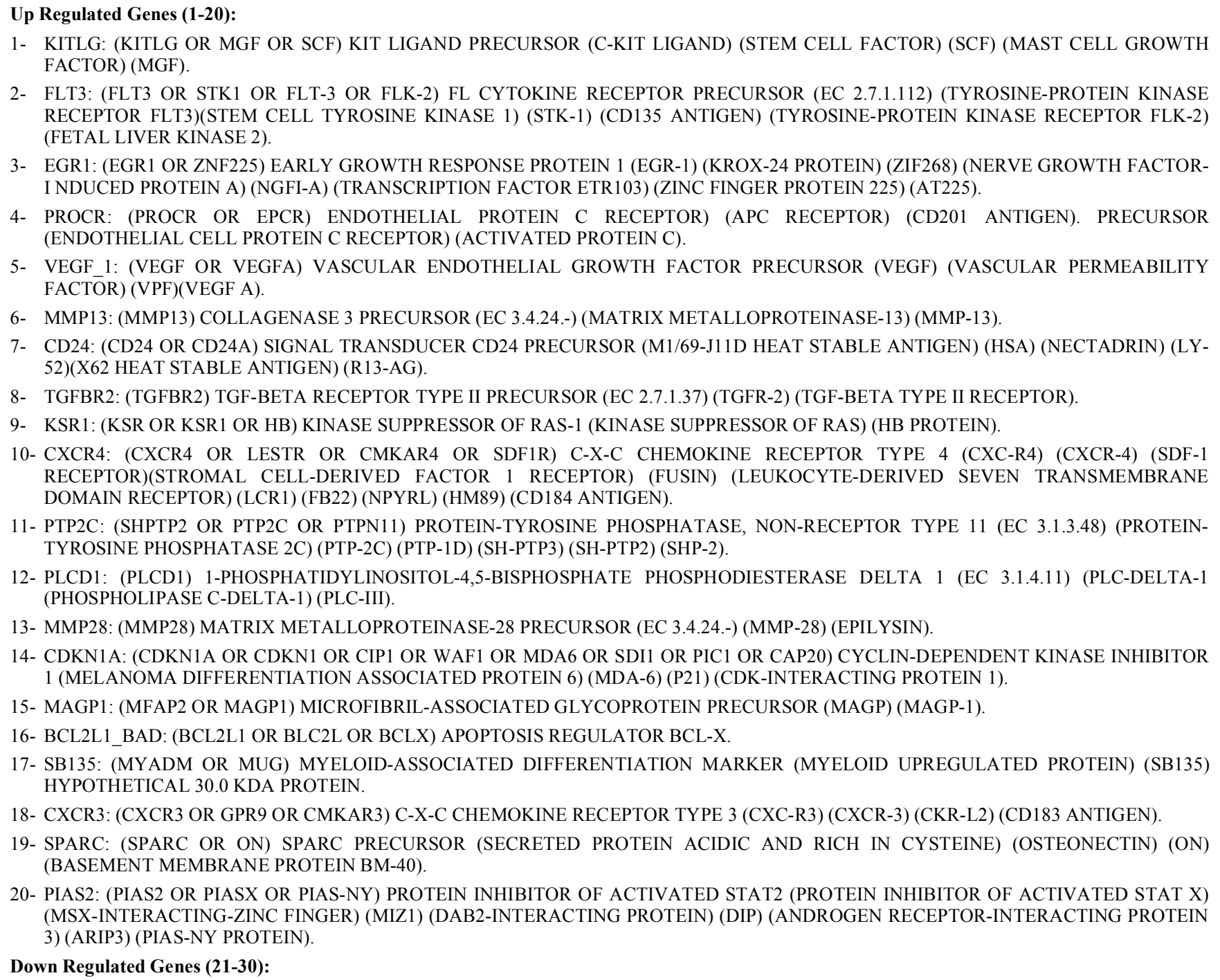

2- FLT3: (FLT3 OR STK1 OR FLT-3 OR FLK-2) FL CYTOKINE RECEPTOR PRECURSOR (EC 2.7.1.112) (TYROSINE-PROTEIN KINASE RECEPTOR FLT3)(STEM CELL TYROSINE KINASE 1) (STK-1) (CD135 ANTIGEN) (TYROSINE-PROTEIN KINASE RECEPTOR FLK-2) (FETAL LIVER KINASE 2).

3- EGR1: (EGR1 OR ZNF225) EARLY GROWTH RESPONSE PROTEIN 1 (EGR-1) (KROX-24 PROTEIN) (ZIF268) (NERVE GROWTH FACTORI NDUCED PROTEIN A) (NGFI-A) (TRANSCRIPTION FACTOR ETR103) (ZINC FINGER PROTEIN 225) (AT225).

4- PROCR: (PROCR OR EPCR) ENDOTHELIAL PROTEIN C RECEPTOR) (APC RECEPTOR) (CD201 ANTIGEN). PRECURSOR (ENDOTHELIAL CELL PROTEIN C RECEPTOR) (ACTIVATED PROTEIN C).

5- VEGF_1: (VEGF OR VEGFA) VASCULAR ENDOTHELIAL GROWTH FACTOR PRECURSOR (VEGF) (VASCULAR PERMEABILITY FACTOR) (VPF)(VEGF A).

6- MMP13: (MMP13) COLLAGENASE 3 PRECURSOR (EC 3.4.24.-) (MATRIX METALLOPROTEINASE-13) (MMP-13).

7- CD24: (CD24 OR CD24A) SIGNAL TRANSDUCER CD24 PRECURSOR (M1/69-J11D HEAT STABLE ANTIGEN) (HSA) (NECTADRIN) (LY52)(X62 HEAT STABLE ANTIGEN) (R13-AG).

8- TGFBR2: (TGFBR2) TGF-BETA RECEPTOR TYPE II PRECURSOR (EC 2.7.1.37) (TGFR-2) (TGF-BETA TYPE II RECEPTOR).

9- KSR1: (KSR OR KSR1 OR HB) KINASE SUPPRESSOR OF RAS-1 (KINASE SUPPRESSOR OF RAS) (HB PROTEIN).

10- CXCR4: (CXCR4 OR LESTR OR CMKAR4 OR SDF1R) C-X-C CHEMOKINE RECEPTOR TYPE 4 (CXC-R4) (CXCR-4) (SDF-1 RECEPTOR)(STROMAL CELL-DERIVED FACTOR 1 RECEPTOR) (FUSIN) (LEUKOCYTE-DERIVED SEVEN TRANSMEMBRANE DOMAIN RECEPTOR) (LCR1) (FB22) (NPYRL) (HM89) (CD184 ANTIGEN).

11- PTP2C: (SHPTP2 OR PTP2C OR PTPN11) PROTEIN-TYROSINE PHOSPHATASE, NON-RECEPTOR TYPE 11 (EC 3.1.3.48) (PROTEINTYROSINE PHOSPHATASE 2C) (PTP-2C) (PTP-1D) (SH-PTP3) (SH-PTP2) (SHP-2).

12- PLCD1: (PLCD1) 1-PHOSPHATIDYLINOSITOL-4,5-BISPHOSPHATE PHOSPHODIESTERASE DELTA 1 (EC 3.1.4.11) (PLC-DELTA-1 (PHOSPHOLIPASE C-DELTA-1) (PLC-III).

13- MMP28: (MMP28) MATRIX METALLOPROTEINASE-28 PRECURSOR (EC 3.4.24.-) (MMP-28) (EPILYSIN).

14- CDKN1A: (CDKN1A OR CDKN1 OR CIP1 OR WAF1 OR MDA6 OR SDI1 OR PIC1 OR CAP20) CYCLIN-DEPENDENT KINASE INHIBITOR 1 (MELANOMA DIFFERENTIATION ASSOCIATED PROTEIN 6) (MDA-6) (P21) (CDK-INTERACTING PROTEIN 1).

15- MAGP1: (MFAP2 OR MAGP1) MICROFIBRIL-ASSOCIATED GLYCOPROTEIN PRECURSOR (MAGP) (MAGP-1).

16- BCL2L1_BAD: (BCL2L1 OR BLC2L OR BCLX) APOPTOSIS REGULATOR BCL-X.

17- SB135: (MYADM OR MUG) MYELOID-ASSOCIATED DIFFERENTIATION MARKER (MYELOID UPREGULATED PROTEIN) (SB135) HYPOTHETICAL 30.0 KDA PROTEIN.

18- CXCR3: (CXCR3 OR GPR9 OR CMKAR3) C-X-C CHEMOKINE RECEPTOR TYPE 3 (CXC-R3) (CXCR-3) (CKR-L2) (CD183 ANTIGEN).

19- SPARC: (SPARC OR ON) SPARC PRECURSOR (SECRETED PROTEIN ACIDIC AND RICH IN CYSTEINE) (OSTEONECTIN) (ON) (BASEMENT MEMBRANE PROTEIN BM-40).

20- PIAS2: (PIAS2 OR PIASX OR PIAS-NY) PROTEIN INHIBITOR OF ACTIVATED STAT2 (PROTEIN INHIBITOR OF ACTIVATED STAT X) (MSX-INTERACTING-ZINC FINGER) (MIZ1) (DAB2-INTERACTING PROTEIN) (DIP) (ANDROGEN RECEPTOR-INTERACTING PROTEIN 3) (ARIP3) (PIAS-NY PROTEIN).

Down Regulated Genes (21-30):

21- CD83: (CD83) ANTIGEN PRECURSOR (CELL SURFACE PROTEIN HB15) (B-CELL ACTIVATION PROTEIN).

22- ITGB7: (ITGB7) INTEGRIN BETA-7 PRECURSOR (INTEGRINB7/).

23- MMP12: (MMP12 OR HME) MACROPHAGE METALLOELASTASE PRECURSOR (EC 3.4.24.65) (HME) (MATRIX METALLO PROTEINASE-12) (MMP-12).

24- ASB4: (ASB4) ANKYRIN REPEAT AND SOCS BOX PROTEIN 4 (ASB-4) (8430401O13RIK) (WUGSC:H GS303P24.1).

25- CCND1: (CCND1 OR PRAD1 OR BCL1) G1/S-SPECIFIC CYCLIN D1 (PRAD1 ONCOGENE) (BCL-1 ONCOGENE).

26- NOD2: (CARD15 OR NOD2 OR IBD1) CASPASE RECRUITMENT DOMAIN PROTEIN 15 (NOD2 PROTEIN). (INFLAMMATORY BOWEL DISEASE PROTEIN 1).

27- DCN-1: (DECORIN) BONE PROTEOGLYCAN II PRECURSOR, (DCN) (PG-S2) (PG40) (PGS2).

28- GADD153: (DDIT3 OR CHOP OR GADD153) GROWTH ARREST AND DNA DAMAGE INDUCIBLE PROTEIN GADD153 (DNA DAMAGE INDUCIBLE TRANSCRIPT 3) (DDIT3) (C/EBP HOMOLOGOUS PROTEIN) (CHOP).

29- L1CAM: (L1CAM OR CAML1 OR MIC5) NEURAL CELL ADHESION MOLECULE L1 PRECURSOR (N-CAM L1) (CD171 ANTIGEN).

30- SKP2_1: (SKP2 OR FBXL1) S-PHASE KINASE-ASSOCIATED PROTEIN 2 (F-BOX PROTEIN SKP2) (CYCLIN A/CDK2-ASSOCIATED PROTEIN P45) (P45SKP2) (F-BOX/LRR-REPEAT PROTEIN.

\section{DISCUSSION}

In contrast to the classical view where aldosterone was dubbed a steroid specifically designed to regulate ion balance in the epithelial cells, it has now been highlighted as a key cardiovascular hormone where the steroid stimulates collagen deposition and left ventricular hypertrophy followed by ventricular remodeling $[14,25,26]$. Aldosterone is known to influence a number of important cardiac and vascular functions such as: inotropism, peripheral resistance, venous return, ventricular ejection, myocardial contractility, cyclooxygenase-2 and interleukin-6 [27] $\mathrm{Na}^{+}-\mathrm{H}$ exchanger isoform-1 [28], basolateral $\mathrm{Na}^{+} / \mathrm{K}^{+} /$ATPase [29, 30], reactive oxygen radicals [31], AP-1 [32], osteopontin [33], and the atrial natriuretic peptide gene product $[34,35]$. 
The present study confirms and further extends our previous observations where the mineralocorticoid receptormediated action of steroid hormones induced the epithelial sodium channel in the endothelium [15]. The organization of endothelial cells into capillary-like networks was influenced by both aldosterone and the diuretic amiloride. The capillary diameter was also found dramatically increased, compared to the controls, as a result of aldosterone treatment [16]. As shown here, the underlying molecular events appear to consist of pleiotropic transactivation of genes that regulate capillary hemostasis in situ. Many other reports have variously demonstrated up and down regulation of c-kit ligand (stem cell factor, scf) [36], early growth response protein 1 (egr-1) [37], endothelial protein c receptor [18], cxcr4 [38], cdk-interacting protein 1-p21, [39], protein inhibitor of activated stat2 (pias2) [40], g1/s-specific cyclin d1 (prad1 oncogene [41, 42], growth arrest and dna damage inducible protein gadd153 [39], neural cell adhesion molecule 11 precursor (n-cam 11) (cd171 antigen) [43]. More recently, whereas one study has shown transcription regulation of many genes by aldosterone [44], in another report this steroid was shown to have no effect on transactivation [45] in human endothelium. Such discrepancies could stem from technical differences and cells used by various investigators.

The pleiotropic gene activation by aldosterone in the vascular endothelium, reported here, is in contrast with the classical view where the action of this steroid would be restricted to the upregulation of only a few genes that regulate the natriferic $\left(\mathrm{Na}^{+}\right)$action of the hormone in the epithelium [12-14]. Just as aldosterone exerts important cardiovascular function $[14,25,26]$ so also this mineralocorticoid appears to assure the genesis, maintenance and renewal of the vascular architecture. Collectively, the vasculature indeed appears to function as an organ that is under the influence of many classes of cell signals and hormones.

\section{ACKNOWLEDGMENTS}

We thank Pr. A. Therwath for many helpful discussions and "Retina France" for financial assistance.

\section{DISCLOSURES}

The authors have no financial conflicts of interest.

\section{REFERENCES}

[1] Carmeliet P. Angiogenesis in health and disease. Nat Med 2003; 9: 653-60.

[2] Griffioen AW, Molema G. Angiogenesis: potentials for pharmacologic intervention in the treatment of cancer, cardiovascular diseases, and chronic inflammation. Pharmacol Rev 2000; 52: 23768.

[3] Molema G, Kroesen BJ, Helfrich W, Meijer DK, de Leij LF. The use of bispecific antibodies in tumor cell and tumor vasculature directed immunotherapy. J Control Release 2000; 14, 64: 229-39.

[4] D'Alessio P. Endothelium as a pharmacological target. Curr Opinion Invest Drugs 2001; 2: 1720-4.

[5] Wang YS, Friedrichs U, Eichler W, Hoffmann S, Wiedemann P. Inhibitory effects of triamcinolone acetonide on bFGF-induced migration and tube formation in choroidal microvascular endothelial cells. Graefes Arch Clin Exp Ophthalmol 2002; 240: 42-8.

[6] Lyden D, Hattori K, Dias S, et al. Impaired recruitment of bonemarrow-derived endothelial and hematopoietic precursor cells blocks tumor angiogenesis and growth. Nat Med 2001; 7: 1194201.

[7] Manley PW, Bold G, Bruggen J, et al. Advances in the structural biology, design and clinical development of VEGF-R kinase inhibitors for the treatment of angiogenesis. Biochim Biophys Acta 2004; 1697: 17-27.

[8] Alobaid N, Alnaeb ME, Sales KM, Seifalian AM, Mikhailidis DP, Hamilton G. Endothelial progenitor cells and their potential clinical applications in peripheral arterial disease. Endothelium 2005; 12: 243-50.

[9] Jia L, Takahashi M, Yoshioka T, Morimoto H, Ise H, Ikeda U. Therapeutic potential of endothelial progenitor cells for cardiovascular diseases. Curr Vasc Pharmacol 2006; 4: 59-65.

[10] Aranda A, Pascual A. Nuclear hormone receptors and gene expression. Physiol Rev 2001; 81: 1269-304.

[11] Schacke H, Docke WD, Asadullah K. Mechanisms involved in the side effects of glucocorticoids. Pharmacol Ther 2002; 96, 23-43.

[12] Agarwal MK. Perspectives in receptor mediated mineralocorticoid hormone action. Pharmacol Rev 1994; 46: 67-87,

[13] Agarwal MK, Mirshahi M. General overview of mineralocorticoid hormone action. Pharmacol Ther 1999; 84: 273-326.

[14] Connell JM, Davies E. The new biology of aldosterone. J Endocrinol 2005; 186: 1-20.

[15] Golestaneh N, Klein C, Valamanesh F, Suarez G, Agarwal MK, Mirshahi M. Mineralocorticoid receptor-mediated signaling regulates the ion gated sodium channel in vascular endothelial cells and requires an intact cytoskeleton. Biochem Biophys Res Commun 2001; 280: 1300-6.

[16] Chen W, Valamanesh F, Mirshahi T, et al. Aldosterone signalling modifies capillary formation by human bone marrow endothelial cell. Asc Pharmacol 2004; 40: 267-77.

[17] Mirsahi M. Aldosterone signaling modifies endothelial cell volume in vitro. Current advance in heart disease. Kimchi A, Ed. Bologna, Italy: Medimond 2008; pp. 365-70.

[18] Ducros E, Berthaut A, Mirshahi SS, et al. Aldosterone modifies hemostasis via upregulation of the protein-C receptor in human vascular endothelium. Biochem Biophys Res Commun 2008; 22; 373(2):192-6.

[19] Kern PA, Knedler A, Eckel RH. Isolation and culture of microvascular endothelium from human adipose tissue. J Clin Invest 1983; 711: 822-9

[20] Mirshahi P, Toprak SK, Faussat AM, et al. Malignant hematopoietic cells induce an increased expression of VEGFR-1 and VEGFR-3 on bone marrow endothelial cells via AKT and mTOR signalling pathways. Biochem Biophys Res Commun 2006; 349(3):1003-10.

[21] Berthaut A, Mirshahi P, Benabbou N, et al. Vascular endothelial growth factor receptor-1 (VEGFR-1) expression in human corneal fibroblast decreased with age. Mol Vis 2009; 29: 15:1997-2007.

[22] Hu X, Li S, McMahon EG, Lala DS, Rudolph AE. Molecular mechanisms of mineralocorticoid receptor antagonism by eplerenone. Mini Rev Med Chem 2005; 5: 709-18.

[23] McMahon EG. Recent studies with eplerenone, a novel selective aldosterone receptor antagonist. Curr Opin Pharmacol 2001; 1: 190-6.

[24] Magni P, Motta M. Aldosterone receptor antagonists: biology and novel therapeutic applications. Curr Hypertens Rep 2005; 7: 20611.

[25] Goodfriend TL, Aldosterone. A hormone of cardiovascular adaptation and maladaptation. J Clin Hypertens (Greenwich) 2006; 8(2): 133-9.

[26] Beygui F, Collet JP, Benoliel JJ, et al. High plasma aldosterone levels on admission are associated with death in patients presenting with acute ST-elevation myocardial infarction. Circulation 2006; 114(24): 2604-10.

[27] Rebsamen MC, Perrier E, Gerber-Wicht C, Benitah JP, Lang U, Direct and indirect effects of aldosterone on cyclooxygenase-2 and interleukin-6 expression in rat cardiac cells in culture and after myocardial infarction. Endocrinology 2004; 145: 3135-42.

[28] Karmazyn M, Liu Q, Gan XT, Brix BJ, Fliegel L. Aldosterone increases NHE-1 expression and induces NHE-1-dependent hypertrophy in neonatal rat ventricular myocytes. Hypertension 2003; 42: 1171-6.

[29] Boixel C, Gavillet B, Rougier JS, Abriel H. Aldosterone Increases Voltage-Gated Sodium Current in Ventricular Myocytes. Am J Physiol Heart Circ Physiol 2006; 290(6): H2257-66 
[30] Ikeda U, Hyman R, Smith TW, Medford RM. Aldosteronemediated regulation of $\mathrm{Na}^{+} / \mathrm{K}^{+} /$ATPase gene expression in adult and neonatal cardiocytes. J Biol Chem 1991; 266: 12058-66.

[31] Callaghan MJ, Ceradini DJ, Gurtner GC. Hyperglycemia-induced reactive oxygen species and impaired endothelial progenitor cell function. Antioxid Redox Signal 2005; 7: 1476-82.

[32] Fiebeler A, Luft FC. The mineralocorticoid receptor and oxidative stress. Heart Fail Rev 2005; 10: 47-52.

[33] Sugiyama T, Yoshimoto T, Hirono Y, et al. Aldosterone increases osteopontin gene expression in rat endothelial cells. Biochem Biophys Res Commun 2005; 336: 163-7.

[34] Ganguly A. Atrial natriuretic peptide-induced inhibition of aldosterone secretion: a quest for mediators. Am J Physiol 1992; 263: E181-94.

[35] Geiger H, Bahner U, Palkovits M. Effects of aldosterone and dexamethasone on atrial natriuretic peptide levels in preoptic and hypothalamic nuclei of adrenalectomized and intact rats. Neuroendocrinology 1991; 53: 63-8.

[36] Boulkroun S, Samson-Couterie B, Golib-Dzib JF, et al. Aldosterone-producing adenoma formation in the adrenal cortex involves expression of stem/progenitor cell markers. Endocrinology 2011; 152(12): 4753-63.

[37] Li X, Meng Y, Yang XS, Wu PS, Zhang ZS. Aldosterone stimulating PDGF-B expression in HSC via activation of EGR-1. Zhonghua Gan Zang Bing Za Zhi. 2005; 13(8): 567-70.

[38] Chu PY, Zatta A, Kiriazis H, et al. CXCR4 antagonism attenuates the cardiorenal consequences of mineralocorticoid excess. Circ Heart Fail 2011; 1; 4(5): 651-8.
[39] Kellner M, Peiter A, Hafner M, et al. Early aldosterone upregulated genes: new pathways for renal disease? Kidney Int 2003; 64(4): 1199-207.

[40] Tirard M, Jasbinsek J, Almeida OF, Michaelidis TM. The manifold actions of the protein inhibitor of activated STAT proteins on the transcriptional activity of mineralocorticoid and glucocorticoid receptors in neural cells. J Mol Endocrinol 2004; 32(3): 825-41.

[41] Yuan Y, Zhang A, Huang S, Ding G, Chen R. A PPARgamma agonist inhibits aldosterone-induced mesangial cell proliferation by blocking ROS-dependent EGFR intracellular signaling. Am J Physiol Renal Physiol 2011; 300(2): F393-402.

[42] Diep QN, El Mabrouk M, Cohn JS, et al. Structure endothelial function, cell growth, and inflammation in blood vessels of angiotensin II-infused rats: role of peroxisome proliferatoractivated receptor-gamma. Circulation 2002; 105(19): 2296-302.

[43] Montaron MF, Piazza PV, Aurousseau C, Urani A, Le Moal M, Abrous DN. Implication of corticosteroid receptors in the regulation of hippocampal structural plasticity. Eur J Neurosci 2003; 18(11): 3105-11.

[44] Sekizawa N, Yoshimoto T, Hayakawa E, Suzuki N, Sugiyama T, Hirata Y. Transcriptome analysis of aldosterone-regulated genes in human vascular endothelial cell lines stably expressing mineralocorticoid receptor. Mol Cell Endocrinol 2011; 341(1-2): 78-88.

[45] Verhovez A, Williams TA, Morello F, et al. Aldosterone does not Modify Gene Expression in Human Endothelial Cells. Horm Metab Res 2011. [Epub ahead of print].

(C) Mirshahi et al.; Licensee Bentham Open.

This is an open access article licensed under the terms of the Creative Commons Attribution Non-Commercial License (http://creativecommons.org/licenses/by-nc/3.0/) which permits unrestricted, non-commercial use, distribution and reproduction in any medium, provided the work is properly cited. 